\title{
Optimasi sterilisasi eksplan pada kultur in vitro ginseng jawa (Talium paniculatum)
}

\author{
Karen Natasha ${ }^{1}$, Ratih Restiani ${ }^{2, ~ *}$ \\ Fakultas Bioteknologi, Universitas Kristen Duta Wacana, \\ Jl. Dr. Wahidin Sudirohusodo No.5-25, Yogyakarta \\ 2 ratih.restiani@staff.ukdw.ac.id* \\ *korespondensi penulis
}

\begin{abstract}
Abstrak
Ginseng jawa (Talinum paniculatum) merupakan salah satu tanaman obat herbal yang mengandung berbagai macam senyawa bioaktif seperti saponin, flavonoid, dan tannin. Senyawa bioaktif tersebut membuatnya berpotensi untuk menyembuhkan berbagai jenis penyakit. Bagian daun ginseng jawa biasa dimanfaatkan untuk menghilangkan batuk berdahak, menyembuhkan radang paru-paru dan sebagai afrodisiak. Kultur in vitro adalah salah satu cara untuk dapat meningkatkan senyawa bioaktif pada daun ginseng. Kendala utama dalam pelaksanaan kultur in vitro adalah kontaminasi. Kontaminasi dapat berasal dari eksplan yang digunakan pada kultur in vitro. Optimasi sterilisasi pada eksplan adalah langkah yang sangat penting pada tahap awal kultur in vitro. Penelitian ini bertujuan untuk mengetahui optimasi sterilisasi eksplan daun pada kultur in vitro ginseng jawa. Optimasi sterilisasi dilakukan dengan menggunakan klorox, benlate dan alkohol dengan berbagai variasi waktu dan konsentrasi. Hasil penelitian menunjukan bahwa teknik pra sterilisasi dengan menggunakan detergen cair $10 \%$ yang ditambahkan dengan tween 80 dan direndam selama 10 menit menyebabkan kontaminasi pada seluruh eksplan berupa jamur. Teknik sterilisasi yang optimum adalah dengan perlakuan pra steril menggunakan detergen cair $10 \%$ yang ditambahkan dengan tween 80 sebanyak 3 tetes direndam selama 45 detik dan alkohol $50 \%$ selama 1 dan 5 menit menghasilkan eksplan yang hidup dan membentuk kalus sebesar $50 \%$ dan $50 \%$ sisanya mengalami nekrosis.
\end{abstract}

Kata kunci: kultur in vitro, sterilisasi, kalus, Talinum paniculatum, alkohol

\begin{abstract}
Javanese ginseng (Talinum paniculatum) is one of the herbal medicinal plants that contains various kind of bioactive compounds such as saponin, flavonoid, and tannin. These bioactive compounds have the potential to cure various types of diseases. Leaves of Javanese ginseng is commonly used to cure cough with phlegm, pneumonia and as an aphrodisiac. In vitro culture is a technique that can be used to increase bioactive compounds in ginseng leaves through callus production. The main problems for implementing in vitro culture is contamination. Optimization of sterilization in explants is a very important step in the early stages of in vitro culture. This study aims to determine the sterilization technique for in vitro culture of Javanese ginseng. Optimization of sterilization is done by using chlorox, benlate and alcohol with various time and concentration. The results showed that the presterilization technique using $10 \%$ liquid detergent added with 80 tween and soaked for 10 minutes caused contamination in all explants in the form of fungi. The optimum sterilization technique is a pre-sterile treatment using a liquid detergent $10 \%$ added with 3 drops of Tween 80 soaked for 45 seconds
\end{abstract}


and 50\% alcohol for 1 and 5 minutes produces 50\% live explants and 50\% necrosis.

Keywords: in vitro culture, sterilization, callus, Talinum paniculatum, alcohol

\section{PENDAHULUAN}

Ginseng jawa (Talinum paniculatum) merupakan salah satu tanaman obat herbal yang telah lama dimanfaatkan masyarakat Indonesia untuk mengobati berbagai jenis penyakit seperti jantung dan insomnia, enuresis, disfungsi seksual, produksi ASI yang minim, TB paru, stamina menurun, keputihan dan haid tidak teratur (Rubatzky, 1998; Munim et al., 2011). Berbagai khasiat yang dimilikinya sangat dipengaruhi oleh senyawa bioaktif dalam ginseng jawa yaitu saponin, steroid, polifenol, dan minyak atsiri(Komatsu, 1992). Khasiat yang dihasilkan oleh Ginseng jawa membuatnya analog dengan khasiat yang dimiliki oleh genseng Korea dan Cina.

Sejauh ini, perbanyakan Ginseng jawa dilakukan dengan menggunakan biji, stek batang maupun umbi, namun cara tersebut memiliki kelemahan seperti untuk menumbuhkan biji sangat tergantung oleh faktor internal biji itu sendiri (faktor fisik dan biologi) sedangkan untuk budidaya menggunakan stek batang memerlukan media pasir untuk mempercepat pertumbuhan akarnya dimana media pasir memiliki kandungan hara yang sangat rendah sehingga akar tidak tumbuh optimum. Budidaya menggunakan umbi membutuhkan waktu yang cukup lama (Hidayat, 2005). Selain itu juga budidaya vegetatif dan generatif ginseng jawa memiliki kelemahan dari segi waktu, sumber tanaman serta kuantitas metabolit sekunder yang terbatas pada umur pemanenan Ginseng jawa.

Salah satu cara untuk mengatasi kelemahan budidaya ginseng jawa tersebut adalah dengan menggunakan metode kultur in vitro. Metode kultur in vitro dapat meningkatkan produksi metabolit sekunder tanaman Ginseng jawa. Perbanyakan akar ginseng jawa (Talinum paniculatum Gaertn.) yang dilakukan menggunakan kultur in vitro terbentuk pada waktu 3 hari sebanyak kurang lebih 38 akar (Dewi, 2016). Induksi akar dari eksplan daun ginseng jawa juga dapat dilakukan secara in vitro yaitu dengan ditambahkan dengan ZPT IBA pada konsentrasi 2mg/L. Selain Ginseng jawa, beberapa penelitian mengenai keberhasilan kultur in vitro juga telah banyak diteliti. Penelitian yang dilakukan Nina Marlina (2009) membuktikan bahwa teknik kultur in vitro mampu memperbanyak bunga potong lili (Lilium longiflorum) melalui pertumbuhan kalus. Rossa Y et al., (2012)juga menyatakan bahwa kultur in vitro melalui jalur embriogenesis mampu menghasilkan pemanjangan tunas, 
multiplikasi tunas, dan induksi perakaran dari tanaman jambu mete (Anacardium occidentale L.) Selain itu, penelitian yang dilakukan oleh Sahriana et al., (2016) menyatakan bahwa perbanyakan kultur in vitro melalui jalur organogenesis mampu menginduksi tunas yaitu 6 hari setelah tanam dan membentuk daun yaitu 3 helai pada tanaman jabon merah (Anthocephalus macrophullus (Roxb)Havil).

Sterilisasi merupakan upaya pemusnahan kontaminasi mikroba yang mungkin muncul pada kultur in vitro.Kontaminasi mikrobia seperti bakteri, virus, khamir dan jamur dapat muncul karena sterilisasi yang kurang optimal sehingga menghambat pertumbuhan eksplan. Hal ini disebabkan karena mikrobia berkompetisi dalam hal nutrisi dengan eksplan. Kontaminasi mikrobia ini juga dapat mempengaruhi kematian jaringan atau yang biasa disebut nekrosis dan menghambat pertumbuhan tunas maupun akar eksplan (Kane, 2003).Mengingat kondisi steril adalah salah satu faktor yang menentukan keberhasilan kultur in vitro, maka pemilihan metode sterilisasi yang tepat sangat penting untuk dioptimasi. Hal yang penting diperhatikan dalam tahap sterilisasi adalah eksplan yang steril dan menjaga agar jaringan dari eksplan tidak rusak akibat dari konsentrasi sterilan yang digunakan (Pancaningtyas, 2011).

Beberapa jenis disinfektan yang umum digunakan dalam kultur in vitro adalah alkohol, klorox, benlate, sodium hipoklorit, $\mathrm{HgCl}$, deterjen dan tween (Felek et al, 2015). Berbagai penelitian yang telah dilakukan terhadap optimasi sterilisasi eksplan dalam kultur in vitro menyatakan bahwa senyawa kimia seperti deterjen dan alkohol yang dikombinasikan dengan waktu perendaman yang tepat cukup baik untuk menurunkan kemungkinan munculnya kontaminasi pada eksplan (Setiani, dkk 2018). Namun, seberapa efektif setiap disinfektan tersebut dalam mengurangi munculnya kontaminasi pada eksplan perlu dikaji lebih jauh dalam penelitian ini. Hal yang sangat penting diperhatikan dalam keberhasilan sterilan dalam mengurangi munculnya kontaminasi diantaranya adalah waktu perendaman eksplan dalam sterilan dan konsentrasi sterilan yang digunakan. Oleh karena itu, tujuan dari penelitian ini adalah untuk mengoptimasi sterilisasi eksplan daun untuk kultur in vitro ginseng jawa.

\section{METODE}

Penelitian ini dilaksanakan di Laboratorium Bioteknologi Universitas Kristen Duta Wacana sejak bulan Januari sampai Agustus 2019. Peneltian dibagi menjadi 4 tahapan meliputi: 
1. Pembuatan Media

Media yang digunakan adalah media MS (Murashige \& Skoog). Media MS mengandung beberapa komposisi penting seperti stok Makronutrien, Mikronutrien, Vitamin, Iron, Myo-inositol, Zat Pengatur Tumbuh dengan menggunakan sukrosa sebagai sumber energi sebesar 18 gram/L dan agar sebagai pemadat sebesar 7 gram/L. Media basal MS ditambahkan dengan berbagai variasi konsentrasi zat pengatur tumbuh 2,4 D, (0;0,5;1;2;3;4;5 ppm) dan Kinetin $(0 ; 0,5 ; 1 ; 2 ; 3 ; 4 ; 5 \mathrm{ppm})$. Pengukuran $\mathrm{pH}$ dilakukan yaitu sekitar 5,7-5,8. Setiap perlakuan uji dilakukan pengulangan sebanyak 4 kali. Media kemudian di sterilisasi basah menggunakan autoclaf dengan suhu $121^{\circ} \mathrm{C}$ dengan tekanan 1 atm selama 15 menit

2. Persiapan Eksplan

Eksplan yang digunakan adalah daun ginseng jawa berusia kurang lebih 1-2 bulan yang diambil dari 3 pucuk teratas yang akan ditumbuhkan dalam media MS.

3. Sterilisasi daun ginseng jawa

Daun ginseng jawa yang akan ditanam sebelumnya dicuci dengan air mengalir dan membuang bagian-bagian yang kotor. Kemudian daun direndam dengan detergen cair (10\%) dan ditambah 3 tetes Tween 80 (perlakuan seperti dalam tabel 1). Lalu daun dicuci dengan akuades steril. Kombinasi perlakuan pra sterilisasi dan sterilisasi eksplan dapat dilihat pada tabel 1.

Tabel 1. Rancangan Teknik Sterilisasi

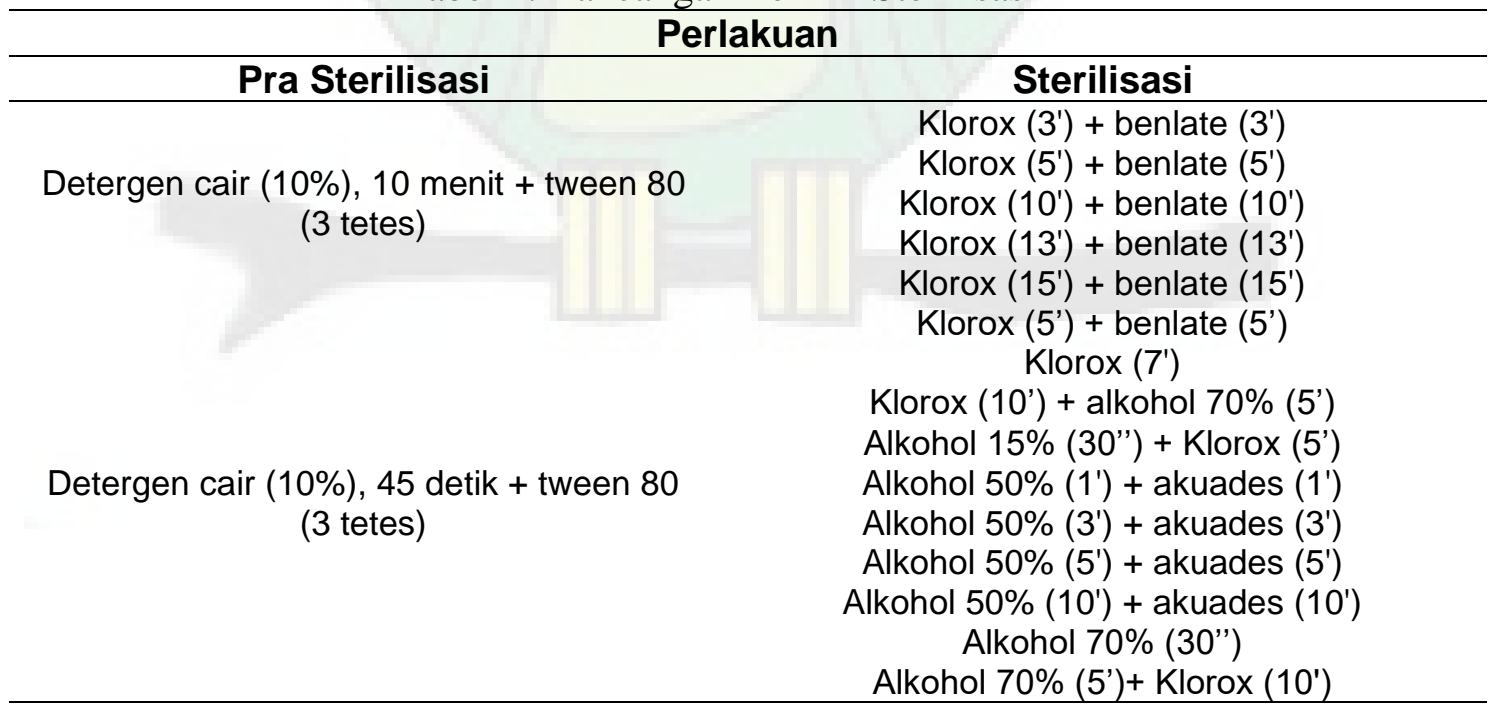

4. Tahap inokulasi

Sebelum melakukan inokulasi, ruang LAF terlebih dahulu disemprot dengan alkohol $70 \%$ pada bagian dinding LAF dan dilap dengan menggunakan tisu. Selanjutnya 
nyalakan sinar UV selama 1 jam. Alat-alat yang akan digunakan untuk inokulasi seperti botol kultur, pinset, scalpel, petri dimasukan ke dalam oven $150^{\circ} \mathrm{C}$ selama 2 jam untuk disterilisasi kering. Inokulasi dilakukan di dalam LAF yang sudah dinyalakan lampu dan blowernya. Penanaman eksplan dilakukan dengan cara mengambil eksplan daun yang sudah dilakukan pra sterilisasi di luar LAF, kemudian eksplan daun di potong di atas cawan petri dengan ukuran $1 \mathrm{~cm}$ x $1 \mathrm{~cm}$ dengan menggunakan scalpel. Lalu eksplan daun ditanam dalam media dengan bagian abaksial yang kontak dengan media. Sebelumnya, mulut botol kultur dipanaskan di atas bunsen untuk menghindari munculnya kontaminasi. Kemudian eksplan ditanam pada media dengan pinset steril. Setelah itu boto kultur ditutup dengan plastik wrap dan diberi label.

\section{HASIL DAN PEMBAHASAN}

Sterilisasi pada eksplan merupakan tahap awal yang sangat penting diperhatikan pada pengembangan kultur in vitro. Jika pada tahap sterilisasi permukaan eksplan tidak berhasil, maka kultur in vitro juga tidak akan dapat diperoleh. Eksplan harus dalam keadaan yang steril agar selanjutnya dapat ditumbuhkan dalam medium in vitro. Jika eksplan tidak steril atau terkontaminasi karena adanya mikroorganisme dari luar lingkungan menyebabkan pertumbuhan eksplan tersebut terhambat. Sterilisasi pada eksplan dapat dilakukan dengan berbagai macam sterilan. Bahan sterilan yang umum digunakan adalah klorox, benlate, dan alkohol. Selain itu, ada juga bahan sterilan yang digunakan pada saat pra sterilisasi, yaitu seperti detergen cair dan tween 80 . Detergen merupakan bahan sterilan yang digunakan untuk menghilangkan lapisan lilin yang melekat di permukaan eksplan dan mengurangi sebagian mikroba yang mungkin masih menempel pada bagian eksplan. Sedangkan tween 80 digunakan sebagai peningkat penetrasi (Akhtar, et al., 2011). Hasil optimasi sterilisasi permukaan pada eksplan daun ginseng jawa dapat dilihat pada Tabel 2.

Tabel 2. Pengaruh perlakuan sterilisasi pada kultur in vitro Talinum paniculatum

\begin{tabular}{|c|c|c|c|c|c|c|}
\hline \multicolumn{2}{|c|}{ Perlakuan } & \multirow{2}{*}{$\begin{array}{c}\text { Waktu } \\
\text { muncul } \\
\text { kontaminasi } \\
\text { / Nekrosis } \\
\text { (HST) }\end{array}$} & \multicolumn{2}{|c|}{$\begin{array}{c}\text { Persentase } \\
\text { Jenis } \\
\text { Kontaminan } \\
(\%) \\
\end{array}$} & \multirow{2}{*}{$\begin{array}{c}\text { Persentase } \\
\text { Nekrosis } \\
(\%)\end{array}$} & \multirow{2}{*}{$\begin{array}{l}\text { Persentase } \\
\text { Eksplan } \\
\text { hidup } \\
(\%)\end{array}$} \\
\hline $\begin{array}{c}\text { Pra } \\
\text { Sterilisasi }\end{array}$ & Sterilisasi & & Jamur & Bakteri & & \\
\hline $\begin{array}{c}\text { Detergen } \\
\text { cair }(10 \%) ; \\
10^{\prime}+\text { tween }\end{array}$ & $\begin{array}{l}\text { Klorox (3 } \\
\text { menit) + } \\
\text { benlate (3 } \\
\text { menit) }\end{array}$ & 7 & 100 & 0 & 0 & 0 \\
\hline 80 (3 tetes) & $\begin{array}{l}\text { Klorox (5 } \\
\text { menit) }+\end{array}$ & 3 & 100 & 0 & 0 & 0 \\
\hline
\end{tabular}




\begin{tabular}{|c|c|c|c|c|c|c|}
\hline \multicolumn{2}{|c|}{ Perlakuan } & \multirow{2}{*}{$\begin{array}{c}\text { Waktu } \\
\text { muncul } \\
\text { kontaminasi } \\
\text { / Nekrosis } \\
\text { (HST) }\end{array}$} & \multicolumn{2}{|c|}{$\begin{array}{c}\text { Persentase } \\
\text { Jenis } \\
\text { Kontaminan } \\
(\%)\end{array}$} & \multirow[t]{2}{*}{$\begin{array}{c}\text { Persentase } \\
\text { Nekrosis } \\
(\%)\end{array}$} & \multirow{2}{*}{$\begin{array}{l}\text { Persentase } \\
\text { Eksplan } \\
\text { hidup } \\
(\%)\end{array}$} \\
\hline $\begin{array}{c}\text { Pra } \\
\text { Sterilisasi }\end{array}$ & Sterilisasi & & Jamur & Bakteri & & \\
\hline & $\begin{array}{c}\text { benlate (5 } \\
\text { menit) }\end{array}$ & & & & & \\
\hline & $\begin{array}{l}\text { Klorox (10 } \\
\text { menit) }+ \\
\text { benlate (10 } \\
\text { menit) }\end{array}$ & 5 & 100 & 0 & 0 & 0 \\
\hline & $\begin{array}{l}\text { Klorox (13 } \\
\text { menit) }+ \\
\text { benlate (13 } \\
\text { menit) }\end{array}$ & 2 & 100 & 0 & 0 & 0 \\
\hline & $\begin{array}{l}\text { Klorox (15 } \\
\text { menit) }+ \\
\text { benlate (15 } \\
\text { menit) }\end{array}$ & 3 & 100 & 0 & 0 & 0 \\
\hline & $\begin{array}{l}\text { Klorox (5 } \\
\text { menit) }+ \\
\text { benlate (5 } \\
\text { menit) }\end{array}$ & 28 & 0 & 0 & 0 & 100 \\
\hline & $\begin{array}{l}\text { Klorox (7 } \\
\text { menit) }\end{array}$ & 24 & 0 & 0 & 0 & 100 \\
\hline & $\begin{array}{l}\text { Klorox (10 } \\
\text { menit) }+ \\
\text { alkohol } 70 \% \\
(5 \text { menit })\end{array}$ & 24 & 0 & 0 & 0 & 100 \\
\hline & $\begin{array}{l}\text { Alkohol 15\% } \\
\text { (30 detik) }+ \\
\text { klorox (5 } \\
\text { menit) }\end{array}$ & 34 & 0 & 0 & 0 & 100 \\
\hline \multirow[t]{6}{*}{$\begin{array}{l}\text { Detergen } \\
\text { cair }(10 \%) ; \\
45 "+\text { tween } \\
80(3 \text { tetes })\end{array}$} & $\begin{array}{c}\text { Alkohol } 50 \% \\
\text { (1 menit)+ } \\
\text { akuades (1 } \\
\text { menit) }\end{array}$ & 31 & 0 & 0 & 0 & 50 \\
\hline & $\begin{array}{c}\text { Alkohol 50\% } \\
\text { (3 menit)+ }\end{array}$ & 31 & 0 & 0 & 0 & 75 \\
\hline & $\begin{array}{c}\text { akuades (3 } \\
\text { menit) }\end{array}$ & & & & & \\
\hline & $\begin{array}{l}\text { Alkohol } 50 \% \\
\text { (5 menit)+ } \\
\text { akuades (5 } \\
\text { menit) }\end{array}$ & 31 & 0 & 0 & 0 & 50 \\
\hline & $\begin{array}{c}\text { Alkohol } 50 \% \\
\text { (10 menit)+ } \\
\text { akuades (10 } \\
\text { menit) }\end{array}$ & 31 & 0 & 0 & 0 & 100 \\
\hline & $\begin{array}{c}\text { Alkohol 70\% } \\
\text { (30 detik) }\end{array}$ & 12 & 0 & 0 & 0 & 100 \\
\hline
\end{tabular}

Berdasarkan hasil penelitian menunjukan bahwa sterilisasi kultur in vitro menggunakan eksplan daun Talinum paniculatum yang paling optimal adalah dengan menggunakan sterilan tunggal alkohol 50\% selama 1 menit dan 5 menit dengan menghasilkan kalus sebesar 50\% 
(Gambar 1C) dan sisanya mengalami nekrosis. Menurut Adji, (2007) alkohol efektif dalam memecah protein yang ada di dalam mikroorganisme sehingga eksplan bisa bebas dari kontaminasi. Tanda-tanda pertumbuhan kalus muncul pada hari ke 31 setelah penanaman. Sedangkan dengan sterilisasi menggunakan sterilan ganda yaitu menggunakan kombinasi 2 sterilan (Klorox + benlete dan Klorox + Alkohol) rata-rata menyebabkan kematian eksplan (nekrosis) yang tinggi yaitu sebesar 100\%. Hal ini mungkin disebabkan karena penggunaan sterilan ganda (lebih dari 1 jenis sterilan) dapat merusak jaringan daun Talinum paniculatum yang tidak terlalu tebal.

Kontaminasi yang muncul dalam kultur in vitro Talinum paniculatum yaitu berupa jamur. Pada setiap perlakuan sterilisasi umumnya kontaminan jamur muncul pada minggu pertama setelah eksplan ditanam. Hal ini mengindikasikan bahwa eksplan jamur tersebut merupakan kontaminan eksternal yang berasal dari permukaan eksplan. Meskipun usaha pencegahan kontaminasi sudah dilakukan secara eksternal dengan menggunakan klorox dan benlate dengan berbagai variasi waktu ternyata belum mampu menghindari eksplan daun dari kontaminasi. Rahmawati (2008) menyatakan bahwa patogen yang muncul mempertahankan dirinya dalam bentuk miselium atau dalam bentuk lain yaitu bisa di dalam embrio, dalam kulit maupun di permukaan eksplan. Kontaminasi berupa jamur terjadi pada permukaan eksplan ditandai dengan munculnya hifa yang menyelimuti eksplan berbentuk kapas berwarna putih dan spora yang berwarna hitam.

Selain kontaminasi, eksplan pada daun ginseng jawa mengalami nekrosis. Penyebab nekrosis adalah rusaknya eksplan daun secara fisiologis yang menunjukan warna daun menjadi kekuningan dan menjadi bening seperti kaca (Gambar 1B). Terjadinya nekrosis dapat disebabkan karena efek fitotoksik dari jenis, konsentrasi dan lama waktu perendaman disinfektan (sterilan) yang digunakan untuk mensterilisasi eksplan sehingga menyebabkan defisiensi klorofil dan kematian jaringan eksplan. Hal lain yang mungkin menyebabkan kematian eksplan adalah karena jumlah pemadat (agar) yang terlalu banyak sehingga nutrien dalam medium tidak dapat diabsorpsi dengan baik oleh eksplan. Selain itu, temperatur dan cahaya yang tidak sesuai di dalam ruang kultur dan kurangnya senyawa-senyawa organik dan anorganik pada media (Pasqualetto, 1990) . 


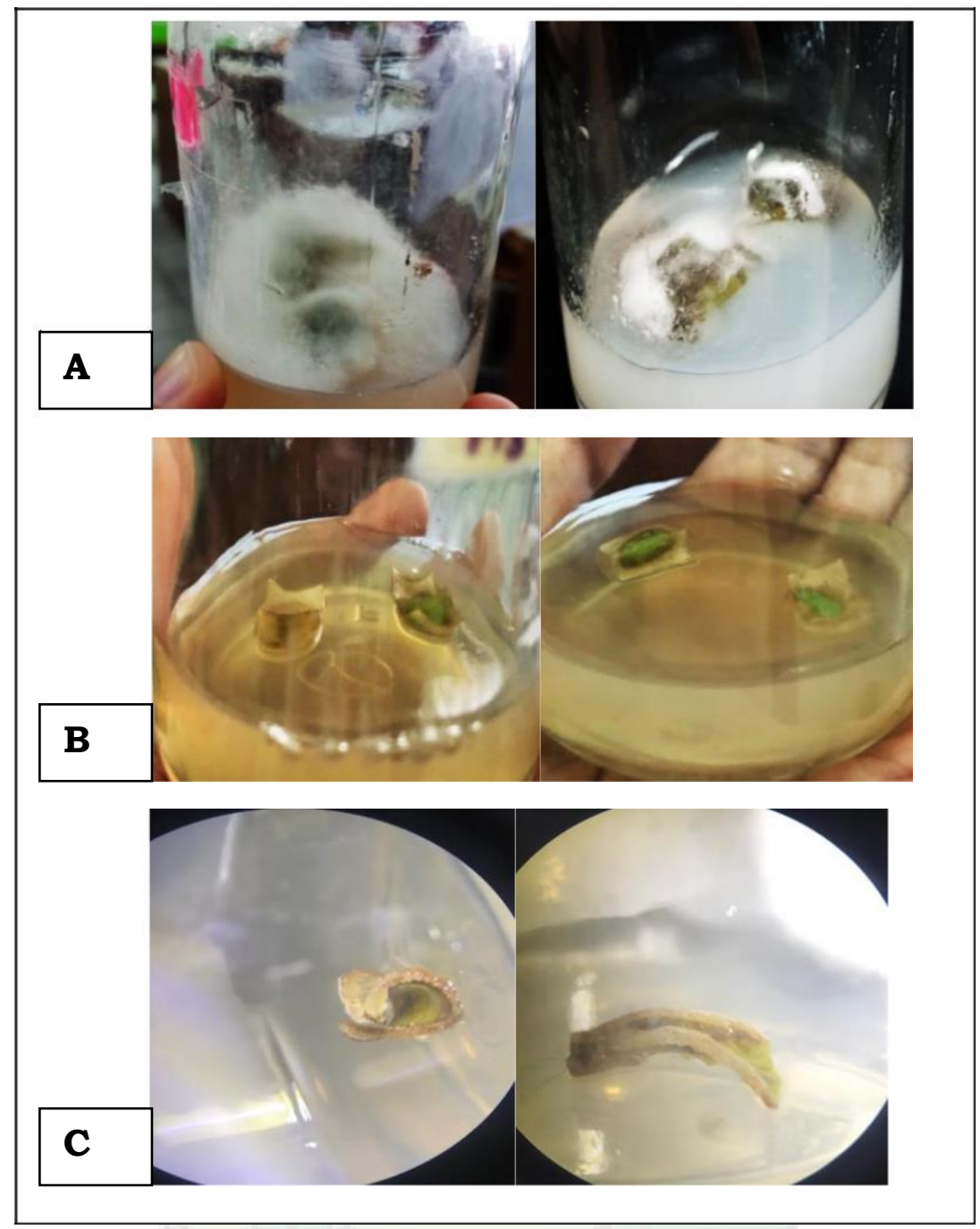

Gambar 1. (A)Eksplan daun ginseng jawa yang terkontaminasi jamur; (B) Eksplan daun ginseng jawa yang mulai mengalami nekrosis; (C) Eksplan daun ginseng jawa yang mulai membentu kalus

\section{SIMPULAN}

Sterilisasi permukaan eksplan pada daun ginseng jawa yang optimal adalah dengan perlakuan pra sterilisasi menggunakan detergen cair 10\% yang ditambahkan dengan Tween 80 selama 45 detik dan perlakukan sterilisasi menggunakan alkohol 50\% dalam waktu 1 dan 5 menit menghasilkan persentase eksplan yang hidup dan membentuk kalus sebesar $50 \%$ dan $50 \%$ sisanya mengalami nekrosis.

\section{REFERENSI}

Adji, Dhirgo. 2007. Perbandingan Efektivitas Sterilisasi Alkohol 70\%, Inframerah,, Otoklaf, dan Ozon terhadap Pertumbuhan Bakteri Bacillus subtilis. Jurnal Sain Veteriner, Volume 25, Nomor 1. Hlm. 17-24. 
Akhtar, N., Rehman, M.U., Khan, H.M.S., Rasool, F., Saeed, T., dan Murtaza, G. (2011). Penetration Enhancing Effect of Polysorbate 20 and 80 on the In Vitro Percutaneous Absorption of L-Ascorbic Acid. Tropical Journal of Pharmaceutical Research. 10(3): 281-288.

Dewi, M. 2016. Perbanyakan Akar Ginseng Jawa (Talinum paniculatum Gaertn.) Pada Variasi Konsentrasi Media Cair dan Zat Pengatur Tumbuh Menggunakan Eksplan Batang Secara in vitro. Disertasi tidak diterbitkan. Surabaya: Program Studi S-1 Biologi Universitas Airlangga.

Felek W; Mekibib, F; Admassu, B. 2015. Optimization of Explants Surface Sterilization condition for field grown peach (Prunus persica L. Batsch. Cv. Garnem) intended for in vitro culture. African Journal of Biotechnology. 14(8), pp. 657-660.

Hidayat S, 2005. Ginseng Multivitamin Alami Berkhasiat, Bogor: Penebar Swadaya.

Izzatul Muhallilin. 2012. Induksi Akar dari EksplanDaun Ginseng Jawa (Talinum paniculatum Gaertn.) dengan Zat Pengatur Tumbuh Auksin Secara In Vitro. Disertasi tidak diterbitkan. Surabaya: Program Studi S-1 Biologi Universitas Airlangga.

Kane M (2003). Bacterial and fungal indexing of tissue cultures. http://www.hos.ufl.edu.moreweb/TissueCulture/class1/Bacterial\%20and\%20fungal\% 20 indexing\%20of20tissue\%20cultures.doc.

Marlina, N. 2009. Teknik Perbanyakan Lili Dengan Kultur Jaringan. Buletin Teknik $\begin{array}{lllll}\text { Pertanian } & \text { Vol. } & 14 & \text { No } 1, \quad 2009: 6-8, & \text { (Online), }\end{array}$ (http://203.190.37.42/publikasi/bt141092.pdf, diakses 1 Agustus 2019).

Munim A, Hanani E. 2011. Fitoterapi Dasar. Jakarta: Dian Rakyat.

Pancaningtyas, S.dan C. Ismayadi. 2011. Sterilisasi Ulang pada Perbanyakan Somatic Embryogenesis Kakao (Theobroma cacao L.) untuk Penyelamatan Embrio Terkontaminasi. Pelita Perkebunan 27 (1).

Pasquoletto PL. 1990. Vitrifi cation in Plant Tissue Culture. In Rodiguez et al. (Eds) Plant Aging vol.186, pp 133-137.

Rahmawati, Melly Siti. 2008. Pengaruh BAP dan GA3 terhadap Perkecambahan Heliconia caribaea Lam. Secara In Vitro. Disertasi tidak diterbitkan. Bogor: Institut Pertanian Bogor

Rubatzky, V. E., 1998, Sayuran Dunia: Prinsip, Produksi dan Gizi Edisi kedua, ITB press, BandungSahriana, M, Muslimin, dan Irmasari. 2016. Organogenesis Tanaman Jabon Merah (Anthocephalus macrophullus (Roxb)Havil)Pada Berbagai Konsentrasi Kombinasi IAA (Indole Acetid Acid) dan BAP (Benzyl Amino Purin) Secara In Vitro.Makalah disajikan dalamWarta Rimba. Universitas Tadulako, Juni 2016.

Setiani, N.A; Nurwinda, F; dan Astiany, D. 2018. Pengaruh Desinfektan dan Lama Perendaman pada Sterilisasi Eksplan Daun Sukun (Artocarpus altilis (Parkinson ex F.A Zorn) Fosberg)

Yunita, R, Ika Mariska dan Chrristiani, T. 2013. Perbanyakan Tanaman Jambu Mete (Anacardium occidentale L.) melalui Jalur Organogenesis. Jurnal AgroBiogen 8(3):113-119, (Online), (https://media.neliti.com/media/publications/73915-IDperbanyakan-tanaman-jambu-mete-anacardiu.pdf, diakses 1 Agustus 2019). 